\title{
Hawaiian Language
}





\section{Hawaiian Language Past, Present, Future}

What Every Teacher and Student of Hawaiian

Might Like to Know about the History

and Future of the Language

Albert J. Schütz

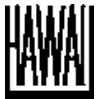

University of Hawai'i Press

Honolulu 
(C) 2020 University of Hawai'i Press

All rights reserved

Printed in the United States of America

$252423222120 \quad 654321$

\section{Library of Congress Cataloging-in-Publication Data}

Names: Schütz, Albert J., author.

Title: Hawaiian language : past, present, and future / Albert J. Schütz.

Description: Honolulu : University of Hawai'i, 2020. | Includes

bibliographical references and index.

Identifiers: LCCN 2019033187 | ISBN 9780824880460 (hardback) | ISBN

9780824869830 (paperback)

Subjects: LCSH: Hawaiian language-History. | Hawaiian

language-Vocabulary. | Hawaiian language-Alphabet.

Classification: LCC PL6441 .S378 2020 | DDC 499/.42-dc23

LC record available at https://lccn.loc.gov/2019033187

University of Hawai' $i$ Press books are printed on acid-free paper and meet the guidelines for permanence and durability of the Council on Library Resources.

Cover art: The Discovery (1928) by Arman Tateos Manookian (Armenian, born Turkey, 1904-1931). Oil on canvas. Courtesy of Collection Elizabeth E. Wong and Isabella N. Wong.

Design by Nord Compo 
To the memory of Dr. Karen M. Peacock-dear friend and wayfinder for all scholars in their Pacific odysseys 
